\title{
LEAGUE OF RED CROSS SOCIETIES
}

Meetings took place from September 29 to October 8, 1966, at the League's headquarters in Geneva in which participated representatives of many National Red Cross, Red Crescent and Red Lion and Sun Societies.

The most important of these was the 86th Session of the Executive Committee of the League of Red Cross Societies. Various other meetings, however, had previously been held, amongst which mention should be made of the Junior Red Cross and the Health and Social Service Advisory Committees which had a joint session on October 3 with a view to studying ways of following up the resolutions of the XXth International Conference concerning the participation by youth and adults in the health educational work of the Red Cross.

The Executive Committee, which numbers twenty-seven members, makes directives to guide the League's activities during the coming year. The 86th Session was opened on October 4 by the League President and President of the Mexican Red Cross, Mr. José Barroso, in the presence of 125 delegates and observers representing fifty-four countries.

The discussions notably bore on the increasingly important rôle of the League in the co-ordination and planning of international disaster relief. The Committee also discussed guidelines for urgent action in the fight against war, disease and natural calamities. Finally, it recommended the implementation of practical projects in such fields as youth in the Red Cross, health education, Red Cross development and planning for relief in disasters.

The Executive Committee, with recommendations from the Junior Red Cross and Health and Social Service Advisory Committees, adopted resolutions appealing :

for youth-especially those from 18 to 25 years-to be more actively involved, alongside adults, in Red Cross health education and other projects, such as the fight against drug addiction, and collaboration in World Health Organization and national health campaigns ; 


\section{IN THE RED CROSS WORLD}

to long-existent National Societies, to provide funds and experts for Red-Cross development projects in newer nations ; and a challenge to these newer National Societies to provide specific development projects ;

to all countries, as a matter of urgency, to develop comprehensive pre-disaster plans involving Government, Red Cross and other agencies and giving each a specific rôle to play in bringing swift relief to disaster victims ;

to National Societies, reminding them that they have an important rôle to play in their countries' campaigns against smallpox and cardio-vascular diseases.

Other resolutions of a more general character were also adopted. We now reproduce two of these.

The resolution on Peace, as Mr. José Barroso remarked in an address preceding a vote on that text by the Executive Committee, demonstrates the same concern as shown in Vienna at the XXth International Conference of the Red Cross, where various resolutions were passed concerning respect for and the application of the Geneva Conventions. Its text is as given below, together with that of the resolution on the Geneva Conventions recommending the parties to the conflict in Vietnam to give their full support to the International Committee.

\section{RESOLUTION No. 24}

\section{The Red Cross and Peace}

The Red Cross is closely attached to the cause of peace. Since its origin it has given proof of this in all circumstances and in all ways. Its work is basically a work of peace.

Through motions and resolutions adopted at its many conferences the International Red Cross has often raised its voice for peace. Today it demands that it must be heard.

That is why the Executive Committee of the League of Red Cross Societies with its 200,000,000 members throughout the world is deeply concerned with the prolongation of an increasingly cruel war in South-East Asia. It urges all parties concerned to put an end to it as soon as possible. 
The Executive Committee requests the Chairman of the Board of Governors to bring this resolution to the notice of the governments and National Societies.

\section{RESOLUTION No. 25}

\section{The Geneva Conventions}

The Executive Committee,

Considering that the International Red Cross has repeatedly emphasized by resolutions its stand on world peace and the responsibility of nations to find means of avoiding war through negotiations,

Urges all of those involved in the present conflict in Vietnam to do everything in their power to bring hostilities to an end;

Meanwhile recalling that in the event of war it is the responsibility of the involved parties to mitigate the suffering and distress of the victims of the conflict,

Urges all the parties engaged in Vietnam to fully support the International Committee of the Red Cross and abide by the Geneva Conventions, and further,

As a gesture of good-will in the first instance, to take immediate action in implementing the section of the Geneva Conventions providing for the repatriation of sick and wounded prisoners of war,

Affirms that the services of the League are always at the disposal of the National Societies of the affected countries for any humanitarian service.

\section{HENRY DUNANT INSTITUTE}

The Henry Dunant Institute originates from a very simple establishment of fact. In order to satisfy the requirements of today, every large-scale enterprise has to concern itself with research, training and information. No progress can in fact be made without research, nor can there be efficiency without ever more advanced training nor can exchanges be made without good channels of information. 